\title{
FLOW IN A LOW-CARBON STEEL AT VARIOUS TEMPERATURES
}

\author{
By H. J. French and W. A. Tucker
}

\begin{abstract}
This report relates to flow (elongation) in 0.25 per cent carbon steel subjected to a fixed total load in tension at approximately constant temperature within the range 70 to $1,100^{\circ} \mathrm{F}$. (20 to $595^{\circ} \mathrm{C}$.). The character of flow is described, and the factors governing selection of maximum allowable stresses are discussed for service in which very long life and freedom from appreciable deformation must be considered. Comparisons are also given between maximum allowable stresses and the stress-strain relations determined in the customary short-time tension tests at various temperatures.
\end{abstract}

\section{CONTENTS}

I. Introduction . .

II. Material tested._.

III. Test methods and equipment employed_...

IV. Experimental results _......

1. Load-life relations.

2. Nature of flow under fixed load and temperature........ 626

3. Relation of life to "initial flow"

4. Relation of life to "final flow" -

5. Relation of life to "secondary flow"

6. Loads producing "no flow" in the second period and their relation to short-time tests..... 630

V. General discussion

VI. Conclusions

\section{INTRODUCTION}

In all cases in which metals are subjected to service at temperatures above atmospheric two main factors are to be considered (1) the physical and constitutional permanence of the material, by which is meant its ability to withstand indefinitely particular stresses or cycles of stress, and (2) its chemical stability. Commercially, wide variations are met in the nature and magnitude of stresses and the atmospheres to which metals are exposed, and therefore a great deal of work is necessary to determine those fields for which a given product is best suited.

In this report only the mechanical properties will be considered, and attention will be further restricted to the case in which a fixed total load is applied in tension at approximately constant temperature to low-carbon structural steel. The fact that the chosen con- 
ditions represent one of the simplest cases encountered makes it easier to develop fundamental flow characteristics which can later be used as a basis of comparison with more complex service data, but there is an added reason for selecting a simple tension stress at constant temperature for preliminary work.

By far the largest number of reported tests have been what may be called "short-time" (ordinary) tension tests. Much of recent discussions relating to the application of metals at high temperatures has centered upon the value of this test method and difficulties encountered in attempting to apply results obtained to practical service conditions. If then, even a qualitative rclationship can be developed between such short-time tension tests and behavior of various metals under sustained loads a vast field of published information will be made available for more rational use; at least, it is probable that greater dependence will be placed generally upon the type of information which can so quickly be secured in the laboratory.

The recent report of long-time tests by Dickenson ${ }^{1}$ in which he characterizes the information obtained in the usual high-temperature tension tests as meaningless and worthless from the standpoint of the designing engineer has done much to point the finger of suspicion at the usefulness of data so derived, in fact, to a greater degree than is warranted by the scope of his work. The authors agree, however, that the tensilc strength values are not a proper basis for determining maximum allowable service stresses at all temperatures if the customary factors of safety are employed. They are not convinced that useful and adequate information can not be obtained from such shorttime tests and in all their work have consistently determined the stress-strain relations, because these, of all factors ordinarily determined, appeared to offer the most logical basis for allowable stress computations. In this respect they are in general agreement with one of the foremost English metallurgists, Harry Brearley, who in discussing Dickenson's "flow" tests remarked that "he was not sure, but he rather fancied that if an autographic stress-strain diagram of hot stoel were carefully made it would be found to contain in itself the suggestion of almost the whole of the information which $\mathrm{Mr}$. Dickenson has so laboriously collected."

The tests to be described in this report form part of a preliminary survey and have a twofold purpose: (1) Study of the flow characteristics of low-carbon steel under fixed loads at constant temperature, and (2) determination of possible relations between long and short time tests or, if nonc is developed, to find a comparatively rapid life test which will give adequate information to engineers for a definite type of service.

1 J.H.S. Dickenson, "Some experiments on the flow of steels at a low red heat, etc.," Jour. I. and S. Inst., 106, p. 103; 1922. 


\section{MATERIAL TESTED}

The material tested was commercial 1-inch hot-rolled boiler plate of the following composition. ${ }^{2}$ Its room-temperature tensile properties are given in Table 6.

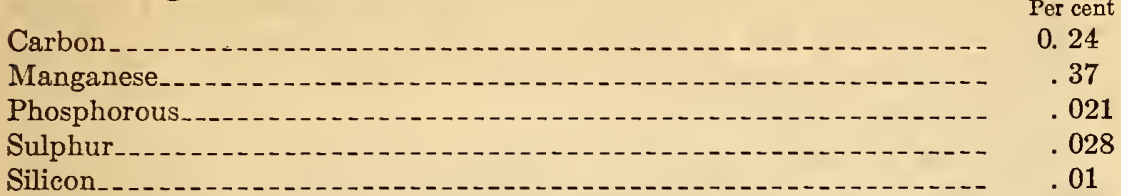

\section{TEST METHODS AND EQUIPMENT EMPLOYED}

Specimens with a reduced section one-fourth inch diameter and 2 inches long (shown in detail in fig. 1) were subjected to a definite load at a predetermined temperature. Both the total applied load and temperature were kept constant within the limits later described. The "flow" (elongation) with time was measured by a telescope micro-

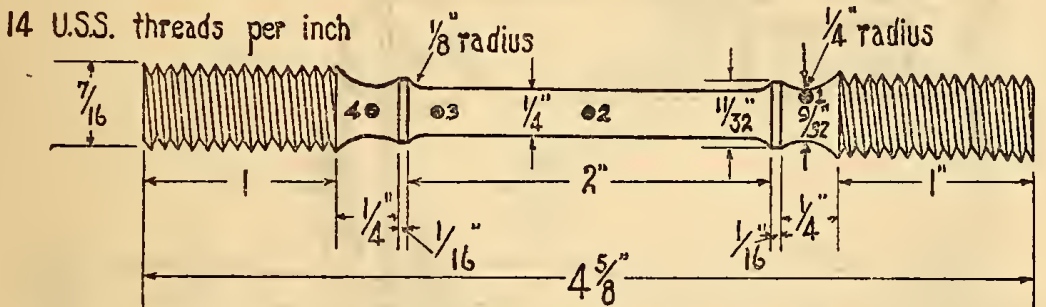

FIG. 1.-Form and dimensions of test specimens used

Nore.-The numbered circles indicate thermocouple positions used in temperature calibration of the heating furnaces, as recorded in Table 1.

meter sighting on suitable marks on the specimen through a window in the heating furnace. In all cases the distance was measured between these marks and the flow then calculated; the method of following the movement of one or both marks on the specimen with respect to a fixed point was not used in any case.

The sharp edges of the "shoulders" or "flanges" at each end of the reduced section of the test specimen form convenient and permanent reference marks for length measurements from which flow is calculated. In the early tests relatively wide shoulders were used in each of which a groove was cut; measurements were made by sighting with the telescope micrometer on small nichrome wires held firmly in these grooves.

The test equipment employed is shown in Figure 2, and while different in details of construction is fundamentally the same as that used by Dickenson. ${ }^{3}$ The desired stress $L$ is applied to the test specimen $S$ by a weight $W$, acting through a mechanical lever system

${ }^{2}$ Acknowledgment is made to the Carnegie Steel Co., Pittsburgh, Pa, for this material.

s See footnote 1, p. 620. 
in which the ratio of lever arms $\left(1^{1}\right.$ and $\left.1^{2}\right)$ is 20 . With the construction illustrated in which this stress is transmitted through a steel cable $C$, bent around a pulley $P$, and in which all pivots consist of steel shafts in steel bearings, frictional losses are encountered and the total load upon the specimen is less than that calculated from the ratio of lever arms and the weight applied at $W$, as is shown in the calibration curve reproduced in Figure 3. However, this loss does not exceed about 5 per cent.

Care must be used in applying weights at $W$ (fig. 2); they must be gently placed upon the weighing table so as not to increase, even momentarily, the load $L$ above the desired value, as such an excess is not readily relieved due to the inertia of the lever system resulting from friction at the pivots or bearings and the cable bent around pulley $P$ (fig. 2).

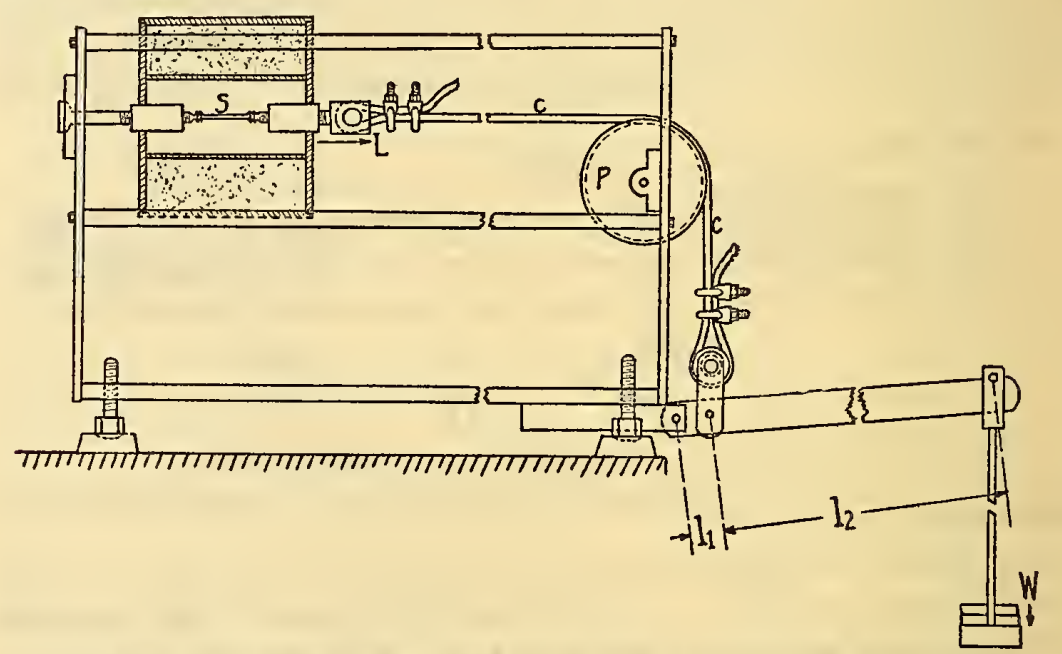

FIG. 2.-Loading equipment used in the flow tests at various temperatures

The test specimen was placed within a tubular electric resistance furnace and then inserted into the pulling heads of the loading device; it was next heated to the desired temperature and the load applied. In the case of rather high loads at the lowest temperatures, heating was first carried out while the specimen was subjected to the dead weight of the weighing table (about 6,500 lbs./in. ${ }^{2}$ on a specimen 0.250 inch in diameter), while, when low stresses were to be sustained, particularly at the highest temperatures, the specimen was heated with only the weight of the lever arm acting upon it (about 1,800 lbs./in. ${ }^{2}$ under similar conditions) or without any load at all. The latter procedure is much to be preferred and was used in all but the preliminary tests.

The distance between the reference marks on the reduced section of the test specimen was carefully measured without load at room temperature, after reaching the desired temperature with no load or only the dead weight acting, and again immediately after the required 
stress was applied; subsequently measurements were made at frequent intervals and flow calculated from the dead weight or "no load"-high temperature value.

As no special features were incorporated in the heating furnaces used, they will not be described in detail. However, the results of a temperature survey of the test specimen in one of these heating units is given in Table 1. Temperature control was maintained by either one of two commercial controllers. With one it was possible to maintain temperatures of the "key" thermocouple within about plus or minus $6^{\circ} \mathrm{F}$. $\left(3^{\circ} \mathrm{C}\right.$.), while with the other temperature variations were within plus or minus $18^{\circ} \mathrm{F} .\left(10^{\circ} \mathrm{C}\right.$. $)$.

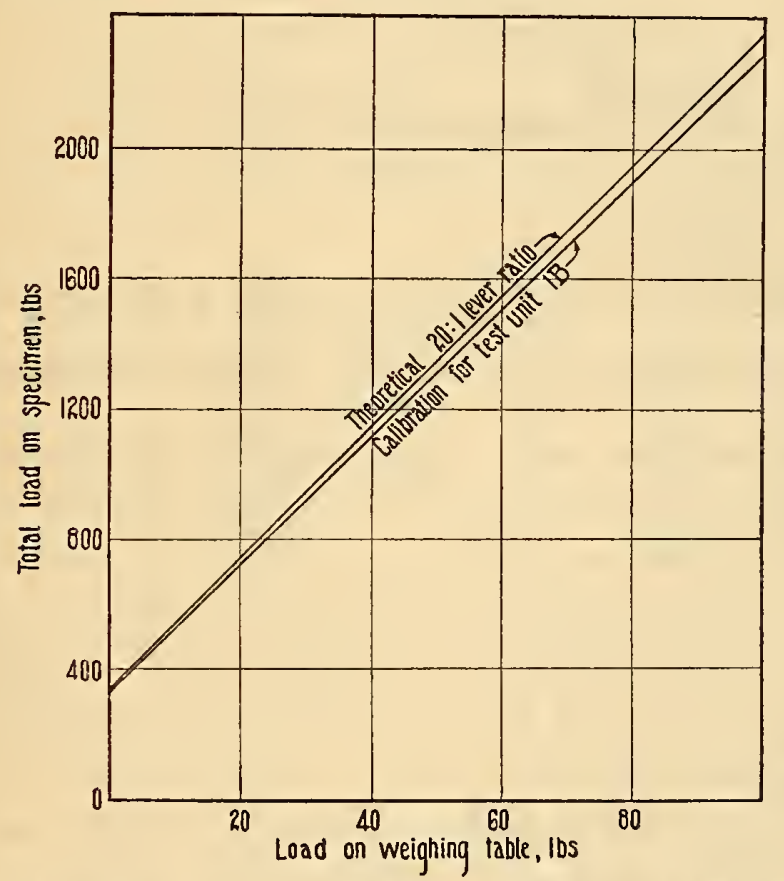

FIG. 3.-Load calibration of one of the flow test units employed

$\mathrm{T}_{\mathrm{ABLE}}$ 1.-Temperature calibration of one of the heating furnaces used (No. $1 \mathrm{~A}$ )

\begin{tabular}{|c|c|c|c|c|c|c|c|}
\hline & \multirow{2}{*}{ Desired temperature } & \multicolumn{4}{|c|}{ Temperature of specimen at position indicated 1} & \multirow{2}{*}{$\begin{array}{c}\text { Time after } \\
\text { thermocou- } \\
\text { ple No. 1 } \\
\text { reached } \\
\text { desired } \\
\text { tempera- } \\
\text { ture }\end{array}$} & \multirow{2}{*}{$\begin{array}{l}\text { Average } \\
\text { tempera- } \\
\text { ture of } \\
\text { thermocou- } \\
\text { ples 2, } 3 \text {, } \\
\text { and 4 }\end{array}$} \\
\hline & & $\begin{array}{l}\text { No. 1"key } \\
\text { couple" }\end{array}$ & No.2 " " & No. 3 "w & No.4" "hory & & \\
\hline $\begin{array}{l}{ }^{\circ} F \text {. } \\
560\end{array}$ & $\begin{array}{l}{ }^{\circ} C . \\
(295)_{-}\end{array}$ & $\begin{array}{r}\circ{ }^{\circ} . \\
561 \\
561 \\
561\end{array}$ & $\begin{array}{r}\circ \\
{ }^{\circ} . \\
565 \\
565 \\
565\end{array}$ & $\begin{array}{r}\circ{ }^{\circ} . \\
547 \\
558 \\
552\end{array}$ & $\begin{array}{r}\circ{ }^{\circ} . \\
543 \\
552 \\
552\end{array}$ & $\begin{array}{r}\text { Minutes } \\
13 \\
23 \\
33\end{array}$ & $\begin{array}{l}\circ F . \\
552 \\
558 \\
556\end{array}$ \\
\hline 810 & $(430)_{-}$ & $\begin{array}{l}813 \\
813 \\
813\end{array}$ & $\begin{array}{l}820 \\
820 \\
820\end{array}$ & $\begin{array}{l}806 \\
810 \\
810\end{array}$ & $\begin{array}{l}792 \\
792 \\
792\end{array}$ & $\begin{array}{l}13 \\
23 \\
33\end{array}$ & $\begin{array}{l}806 \\
807 \\
807\end{array}$ \\
\hline 1,000 & $(540)$ & $\begin{array}{l}1,004 \\
1,004 \\
1,004\end{array}$ & $\begin{array}{l}1,018 \\
1,018 \\
1,018\end{array}$ & $\begin{array}{l}1,002 \\
1,004 \\
1,004\end{array}$ & $\begin{array}{l}986 \\
990 \\
990\end{array}$ & $\begin{array}{l}13 \\
23 \\
33\end{array}$ & $\begin{array}{l}1,002 \\
1,004 \\
1,004\end{array}$ \\
\hline
\end{tabular}

1 The positions corresponding to the numbers given are shown in Figure 1. 
The telescope micrometer used was calibrated in millimeters with smallest direct reading on the vernier equal to 0.005 . While a more

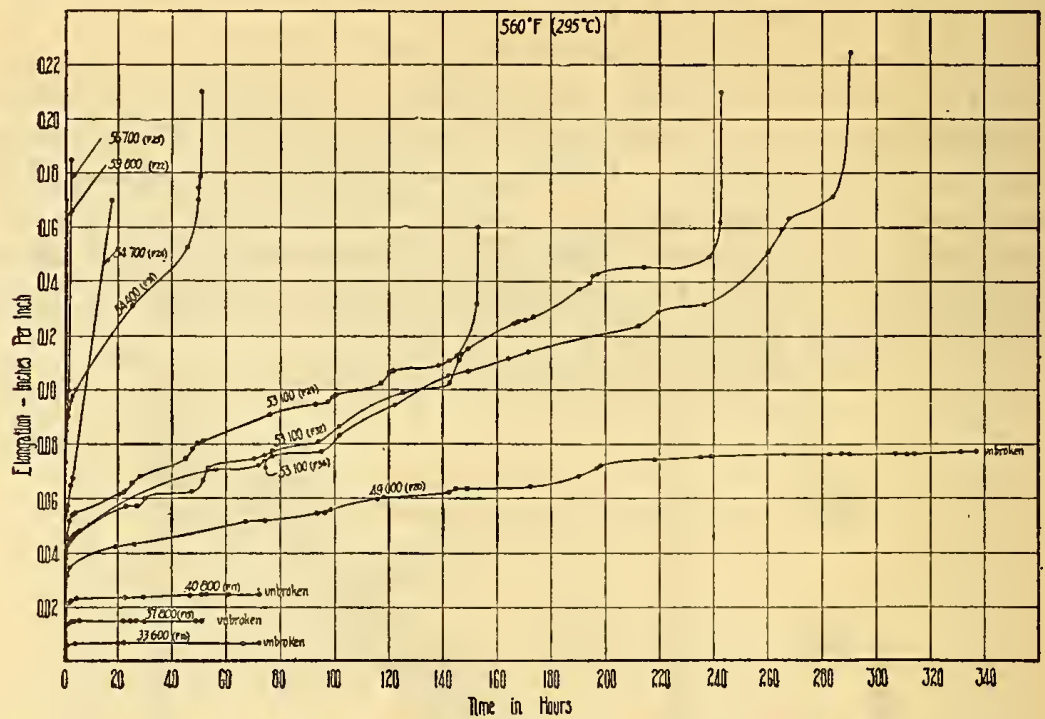

FIG. 4.-Flow in 0.24 per cent $C$ steel under sustained tension loads at $560^{\circ} \mathrm{F}$. ( $295^{\circ}$ C.)

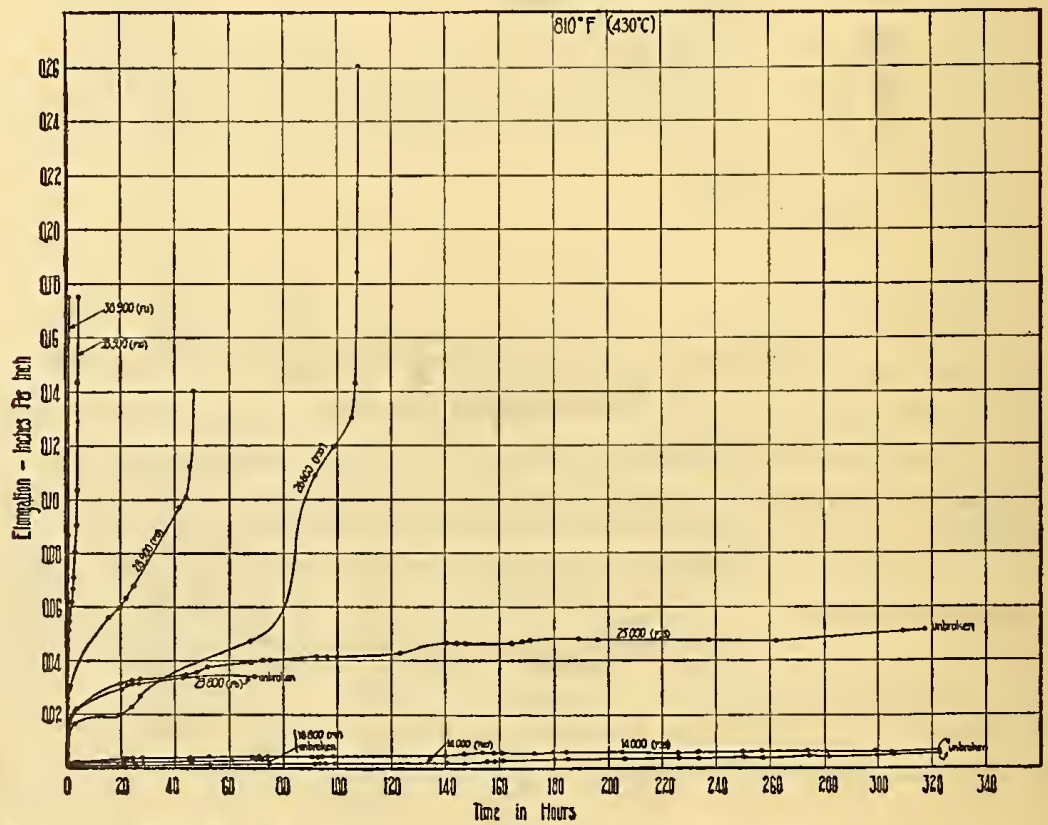

FIG. 5.-Flow in 0.24 per cent $C$ steel under sustained tension loads at $810^{\circ} \mathrm{F}$. $\left(430^{\circ}\right.$ C.)

accurate instrument would have been helpful, the measurements obtained appeared generally satisfactory for the work in view. 


\section{EXPERIMENTAL RESULTS}

It is well known that there is a marked change in the short-time tension test values for low-carbon steels when the temperature is raised above blue heat (about $560^{\circ} \mathrm{F} .\left(295^{\circ} \mathrm{C}\right.$.)) ; the strength factors decrease rapidly, and the ductility, as represented by elongation and reduction of area, increases. Therefore, preliminary flow tests were restricted to two temperatures, one in the blue-heat range, $560^{\circ} \mathrm{F}$. $\left(295^{\circ} \mathrm{C}.\right)$, and one well above, $810^{\circ} \mathrm{F}$. $\left(595^{\circ} \mathrm{C}\right.$.). Results obtained are shown graphically in Figures 4 and 5 and summarized in Tables 2 and 3.

TABLE 2.-Results of flow tests of 0.24 per cent $C$ steel at $560^{\circ} \mathrm{F}$. (295 $\left.{ }^{\circ} \mathrm{C}.\right)$

\begin{tabular}{|c|c|c|c|c|c|c|c|}
\hline Specimen number & $\begin{array}{c}\text { Test } \\
\text { unit } \\
\text { num- } \\
\text { ber }\end{array}$ & $\begin{array}{c}\text { Applied } \\
\text { load } \\
\text { Ibs./in. on } \\
\text { original } \\
\text { area }\end{array}$ & $\begin{array}{l}\text { Elonga- } \\
\text { tion at } \\
\text { failure in } \\
2 \text { incbes }\end{array}$ & $\begin{array}{l}\text { Final } \\
\text { reduction } \\
\text { of area }\end{array}$ & $\begin{array}{l}\text { "Initial } \\
\text { flow," } \\
\text { inch per } \\
\text { incb }\end{array}$ & $\begin{array}{c}\text { A verage } \\
\text { flow rate } \\
\text { in second } \\
\text { stagc, incb } \\
\text { per inch } \\
\text { per hour }\end{array}$ & Life \\
\hline $\begin{array}{l}\text { F22 } \\
\text { F25 } \\
\text { F24 } \\
\text { F292 } \\
\text { F31 } \\
\text { F34 } \\
\text { F32 } \\
\text { F27 } \\
\text { F26 } \\
\text { F36 } \\
\text { F20 } \\
\text { F18 } \\
\text { F17 } \\
\text { F15 } \\
\text { F16 }\end{array}$ & $\begin{array}{l}1 \mathrm{~B} \\
1 \mathrm{~B} \\
1 \mathrm{~B} \\
1 \mathrm{~B} \\
1 \mathrm{~B} \\
1 \mathrm{~B} \\
1 \mathrm{~B} \\
1 \mathrm{~B} \\
1 \mathrm{~B} \\
1 \mathrm{~B} \\
1 \mathrm{~A} \\
1 \mathrm{~B} \\
1 \mathrm{~A} \\
1 \mathrm{~A}\end{array}$ & $\begin{array}{l}59,800 \\
56,700 \\
54,760 \\
54,400 \\
54,460 \\
53,160 \\
53,100 \\
53,100 \\
52,400 \\
52,400 \\
49,000 \\
44,100 \\
40,800 \\
37,800 \\
33,600\end{array}$ & $\begin{array}{r}17.0 \\
18.5 \\
17.0 \\
221.0 \\
21.0 \\
22.5 \\
21.0 \\
216.0 \\
20.0\end{array}$ & $\begin{array}{r}\text { Per cent } \\
42.9 \\
61.3 \\
59.0 \\
261.1 \\
61.3 \\
61.2 \\
61.2 \\
259.1 \\
253.1 \\
\end{array}$ & $\begin{array}{l}(1) \\
(1) \\
(1) \\
0.0995 \\
.0456 \\
.0447 \\
.0517 \\
.0470 \\
.0525 \\
.0384 \\
.0210 \\
.0130 \\
.0058\end{array}$ & $\begin{array}{c}0.405 \\
.022250 \\
.004925 \\
.001160 \\
.000444 \\
.000498 \\
.000436 \\
.000350 \\
.000262 \\
.000186 \\
.000086 \\
.000028 \\
\text { Zero. } \\
.000006\end{array}$ & $\begin{array}{l}\text { Hours } \\
0.2 \\
2.8 \\
17.4 \\
210.8 \\
50.6 \\
290.5 \\
242.8 \\
2152.2 \\
(3) \\
(4) \\
2570 \\
\text { (s) } \\
\text { (s) } \\
\text { (8) } \\
\text { (s) }\end{array}$ \\
\hline
\end{tabular}

1 Continuous.

- Power on controller was interrupted, or for other reasons there was a temperature change during test.

8 Unbroken at 114 hours. "Unbroken at 1,538 bours. 5 Unbroken at 72 bours. 6 Unbroken at 111 bours.

TABLE 3.-Results of flow tests of 0.24 per cent $\mathrm{C}$ steel at $810^{\circ} \mathrm{F}$. (430 $\mathrm{C}$.)

\begin{tabular}{|c|c|c|c|c|c|c|c|}
\hline Specimen number & $\begin{array}{l}\text { Test } \\
\text { unit } \\
\text { num- }\end{array}$ & $\begin{array}{l}\text { Applied } \\
\text { load } \\
\text { Ibs./in. }{ }^{2} \text { on } \\
\text { original } \\
\text { area }\end{array}$ & $\begin{array}{l}\text { Elonga- } \\
\text { tion at } \\
\text { failure in } \\
2 \text { incbes }\end{array}$ & $\begin{array}{l}\text { Final } \\
\text { reduction } \\
\text { of area }\end{array}$ & $\begin{array}{l}\text { "Initial } \\
\text { flow," } \\
\text { incb per } \\
\text { inch }\end{array}$ & $\begin{array}{l}\text { Average } \\
\text { flow rate } \\
\text { in second } \\
\text { stage, incb } \\
\text { per inch } \\
\text { per hour }\end{array}$ & Life 1 \\
\hline $\begin{array}{l}\text { F12 } \\
\text { F11 } \\
\text { F10 } \\
\text { F99 } \\
\text { F72 } \\
\text { F13 } \\
\text { F7 } \\
\text { F35 } \\
\text { F33 } \\
\text { F6 } \\
\text { F8 } \\
\text { F39 } \\
\text { F40 }\end{array}$ & $\begin{array}{l}1 \mathrm{~A} \\
1 \mathrm{~A} \\
1 \mathrm{~A} \\
1 \mathrm{~A} \\
1 \mathrm{~A} \\
1 \mathrm{~A} \\
1 \mathrm{~A} \\
1 \mathrm{~B} \\
1 \mathrm{~A} \\
1 \mathrm{~A} \\
1 \mathrm{~B} \\
1 \mathrm{~B} \\
1 \mathrm{~A}\end{array}$ & $\begin{array}{l}49,000 \\
38,900 \\
33,500 \\
30,800 \\
30,000 \\
28,900 \\
26,600 \\
26,600 \\
25,000 \\
23,800 \\
16,800 \\
14,000 \\
14,000\end{array}$ & $\begin{array}{r}25.0 \\
17.5 \\
17.5 \\
17.5 \\
24.5 \\
14.0 \\
\left({ }^{(5)}{ }^{26.0}\right. \\
(5)\end{array}$ & $\begin{array}{r}\text { Per cent } \\
57.1 \\
53.0 \\
49.0 \\
51.0 \\
76.5 \\
38.8 \\
(\text { () } 73.5 \\
(6) \\
\end{array}$ & $\begin{array}{l}(2) \\
(2) \\
(2) \\
10.0297 \\
.0225 \\
.0155 \\
.0225 \\
.0260 \\
.0020 \\
.0011 \\
.0025\end{array}$ & $\begin{array}{l}14.92 \\
.0835 \\
.0142 \\
.005800 \\
.001633 \\
.000875 \\
.000525 \\
.000210 \\
.000184 \\
.000010 \\
.000020 \\
.000031\end{array}$ & $\begin{array}{c}\text { Hours } \\
\left({ }^{9}\right) \\
1.2 \\
5 \\
(14)^{4.5} \\
4.5 \\
47 . \\
(100) \\
118.7 \\
(1,950) \\
(7) \\
(8)\end{array}$ \\
\hline
\end{tabular}

1 Values in parentbeses are approximations (probably very close to true life) due to failure of timing or recording devices or other reasons for not obtaining complete records.

2 Continuous.

3 Practically zero.

4 In tbese values tbe "no load at temperature" readings were estimated from readings taken inmediately after load was applied.

${ }_{5}^{5}$ Unbroken at 67.5 bours. 'Unbroken at 1,800 bours. TUnbroken at 70 bours. 8 Unbroken at 68.5 hours. $55063^{\circ}-25 \dagger-2$ 


\section{LOAD-LIFE RELATIONS}

There appears to be a hyperbolic relation between the total applied load and the life of the steel, though additional tests will be necessary to establish the exact form of the load-life curves shown in Figure 6, particularly under conditions in which fracture occurs between 1,000 and 10,000 hours. Such tests naturally will require considerable time, so that it would be desirable to find, from the tests already made, some factor related to life; it would then be reasonable to extrapolate for conditions resulting in very long or practically infinite life.

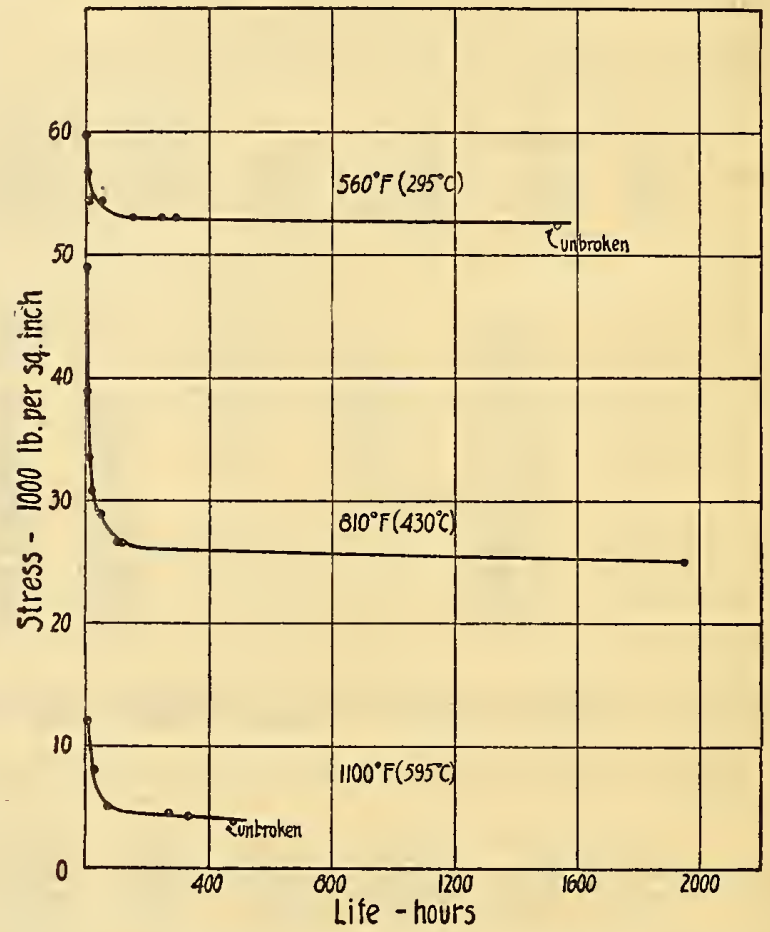

FiG. 6.-Relation between applied load and the life of 0.24 per cent $C$ steel at various temperatures

\section{NATURE OF FLOW UNDER FIXED LOAD AND TEMPERATURE}

It will be noted in studying Figures 4 and 5 that several definite characteristics are shown in practically all time-flow curves. Upon application of load the steel elongates for an appreciable time; the amount of this flow at a given temperature becomes greater with the applied load. If the load is not too large, this "initial flow". ceases after a time, or at least the rate of flow drops materially and quite abruptly and indicates a "strain-hardening" of the material, while with large loads flow continues uninterruptedly until fracture occurs. 
Subsequent to the initial flow, when intermediate or small loads are applied, a fairly uniform flow rate is maintained, and this will hereafter be referred to as the "secondary flow." There is some evidence that this takes place in "jumps"; that is, repeated small elongations followed by periods of little or no flow, possibly indicative of a progressive and repeated strain-hardening of the metal. Whether or not this is a property of the material is open to question, as the observed effects are small and may be the result of temperature variations in combination with errors introduced in to the length measurements by inaccuracies in the micrometer screw.

While the total applied load is kept constant throughout each test, appreciable elongation is accompanied by a reduction in cross-sectional area and a resulting increase in the unit stress. Therefore, the secondary flow period is followed by a final rapid flow which begins when the unit stress exceeds a definite value at each temperature. The last rapid flow before fracture will hereafter be referred to as the "final flow."

Thus it appears that the total elongation which has taken place at fracture has been attained in three distinct steps, the importance of which for a low-carbon steel vary with the total applied load and the temperature of test. These three steps are (1) an initial flow; (2) a secondary flow at fairly constant rate, which is also considerably less than the rate during the first and third periods; and (3) a final rapid flow just before fracture. The relation between each of these and the life of the metal will next be considered.

\section{RELATION OF LIFE TO INITIAL FLOW}

Mention has already been made that the initial flow decreases with the applied load, and likewise that a hyperbolic relation was found between load and life in which one factor increased while the other decreased. It therefore follows that the life increases with decrease in the "initial flow"; this relation also appears to be hyperbolic, as shown in Figure 7, but it is difficult to more than approximate the order of magnitude of initial flow which would accompany infinite life from data now at hand.

\section{RELATION OF LIFE TO FINA:, FLOW}

Since the final rapid flow just before fracture is the result of increased unit stress brought about by reduction in cross section while the steel elongates in the second stage it will not be in direct relation to the life, but is associated with the composition and quality of the steel and temperature of test. 


\section{RELATION OF LIFE TO SECONDARY FLOW}

The initial and final stages of flow play an important part in the failure of the metal, but examination of Figures 4 and 5 shows that by far the largest part of the total elongation resulting in fracture is produced during the second interval. As the average flow rate in this stage is considerably less than that in either the initial or final periods, it is evident that the secondary flow is most important in determining the life of the metal. This is particularly well shown under conditions of low load and long life, such as would have to exist in commercial service.

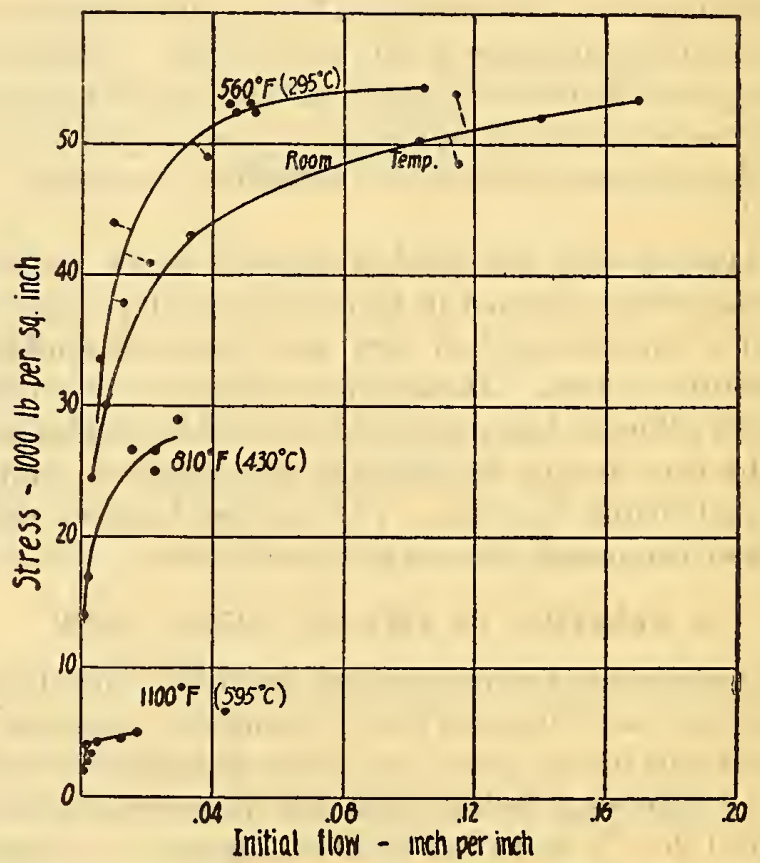

Fig. 7.-Relation between applied load and the "initial flow" in 0.24 per cent $C$ steel at various temperatures

If the average secondary flow rate is compared with the life of the specimens, a hyperbolic relation is again obtained as illustrated in Figure 8. While the exact form of the curves has not been established they will be closely approximated (within the ranges covered in the

experiments) by the general formula $L=\frac{c}{R^{n}}$, in which

$L=$ life in hours,

$R=$ flow rate in the second stage in inches per inch per hour, $c$ and $n=$ constants for a given material and temperature. 
Irrespective of the numerical values of constants $c$ and ${ }^{n}$ the life $L$ will be infinite only when the rate of flow $R$ is zero or, under conditions of practical service, very nearly so.

It has already been shown in a general way that with decrease in the applied stress the life increases and the initial flow decreases. If then the secondary flow rate is zero, the steel will not elongate sufficiently to reach the final rapid flow stage, and fracture will theoretically never be obtained; at least the steel will have a very long life which, from the standpoint of engineering applications, may be called infinite.

The importance of zero flow rate and the determination of the loads resulting in "no flow" during the second stage is emphasized

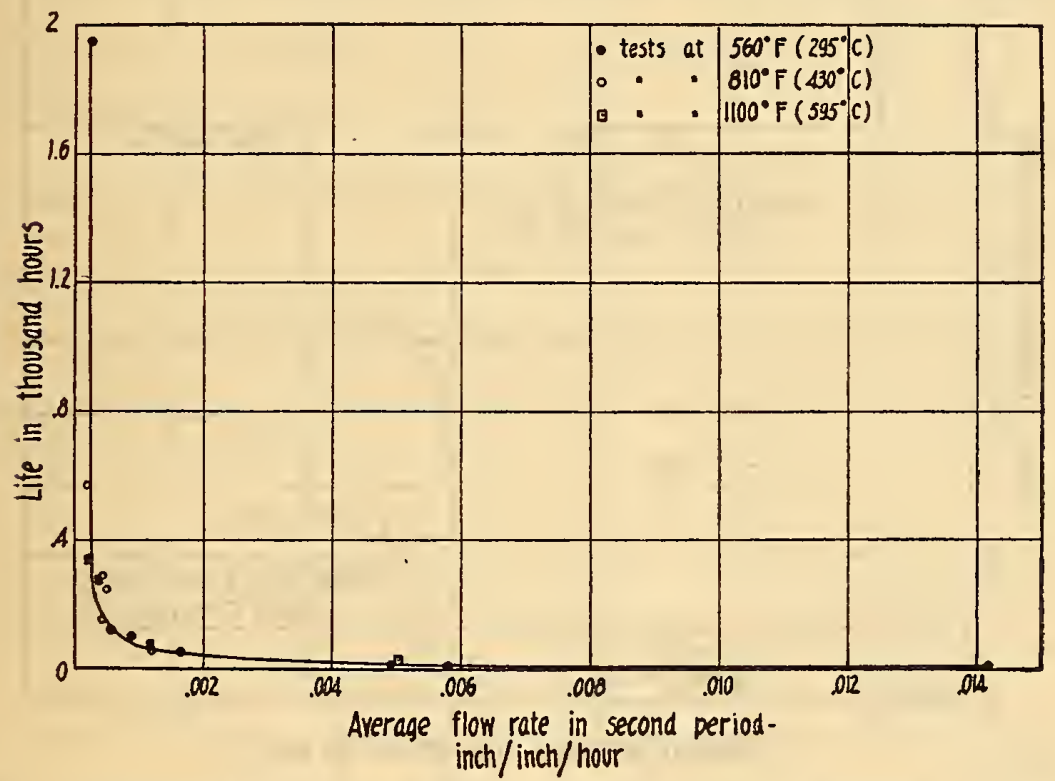

Fig. 8.-Relation between life of 0.24 per cent $C$ steel and the average rate of flow in the second period at various temperatures

when practical service requirements are considered. Not only must the metal be able to resist fracture for a stated time (usually an infinitely long period), but it must not deform appreciably during its life, as such deformation will generally be a serious matter in the customary built-up structures and likewise have to be considered as a failure of the metal.

Obviously, these loads which give "no flow" in the second period appear to be equivalent to the maximum allowable service stresses, provided a certain amount of initial deformation is permitted, and it now remains to study possible relations between them and shorttime tests. 
6. LOADS PRODUCING "NO FLOW" IN THE SECOND PERIOD AND THEIR RELATIONS TO SHORT-TIME TESTS

In Figure 9 is given the relation between the sustained load and secondary flow rate and also a comparison with stress-strain relations obtained in ordinary tension tests ${ }^{4}$ at corresponding temperatures. At $560^{\circ} \mathrm{F}$. $\left(295^{\circ} \mathrm{C}\right.$.) the load giving "no flow" in the second period is approximately $35,000 \mathrm{lbs} . / \mathrm{in} .^{2}$, or twice the proportional limit of the short-time test at the same temperature. It is a little more than half the tensile strength and practically equal to the yield point of the metal which is quite frequently accepted as the proper criterion

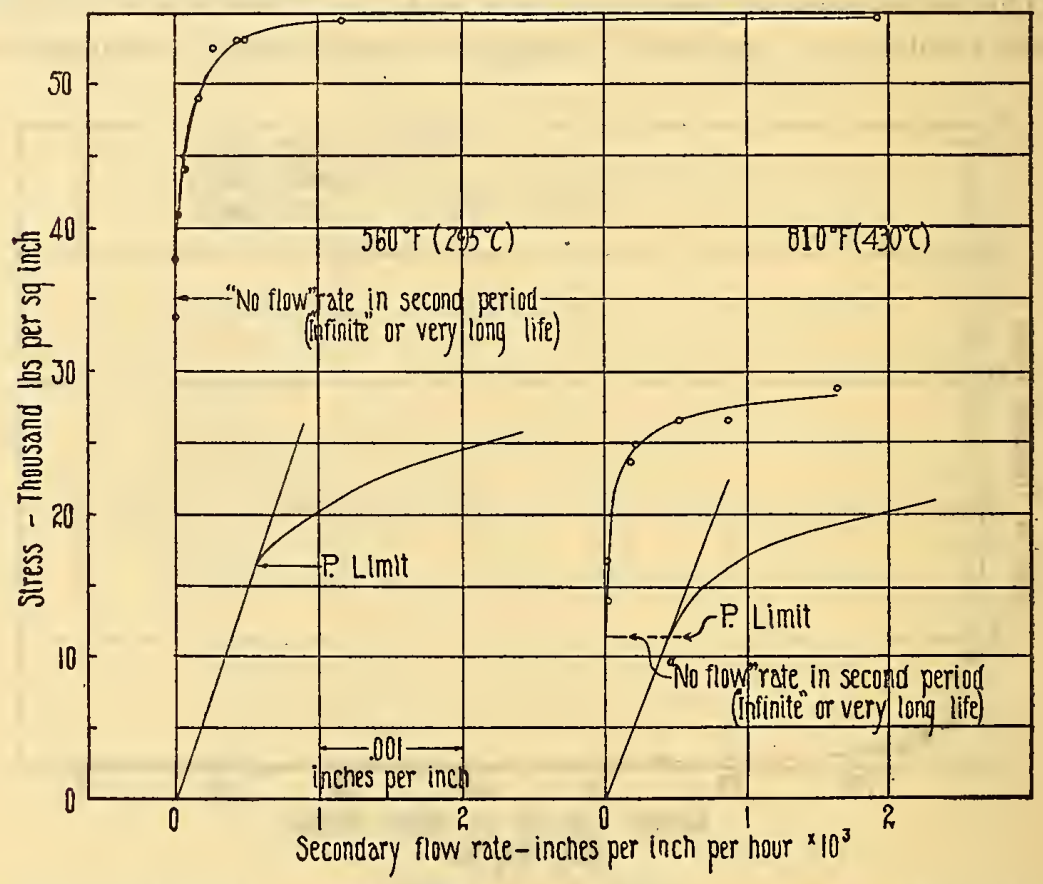

FIG. 9.-Comparison of the average flow rate in the second period with the stressstrain relations in short-time tension tests on 0.24 per cent $C$ steel at 560 and $810^{\circ} \mathrm{F}$. (295 and $430^{\circ} \mathrm{C}$.)

for design of structures subjected to static tension stresses at ordinary temperatures. At $810^{\circ} \mathrm{F}$. $\left(430^{\circ}\right.$ C.) the load giving "no flow" in the second period equals the proportional limit of the authors" tension tests.

These comparisons indicate that the stress-strain relations in carefully made short-time tests contain adequate information for computing allowable working stresses for service under constant temperature and load, but additional data must be obtained before it is possible to generalize on the correct interpretation of results.

4 The ordinary tension tests were made with equipment and procedure described in B. S.'Tech. Paper No. 219, except when otherwise specified. 
As the load-carrying ability, represented by "no flow" in the second period, is well above the proportional limit of the short-time test at $560^{\circ} \mathrm{F}$. $\left(295^{\circ}\right.$ C. $)$ and is practically equal to the latter at $810^{\circ} \mathrm{F}$. $\left(430^{\circ} \mathrm{C}\right.$. $)$, the question may properly be asked whether it is below at higher temperatures. In other words, does the curve representing the maximum allowable stress, determined in the manner described, decrease more rapidly with increase in temperature and finally cross the proportional limit-temperature curve of the customary tensile test, or does it continue to approximate the proportional limit at temperatures higher than $810^{\circ} \mathrm{F} .\left(430^{\circ} \mathrm{C}\right.$.) ?

To answer this question and throw more light upon the effect of temperature on the ability of low-carbon steel to strain harden both long-time and the customary tension tests were made at room temperature and at $1,100^{\circ} \mathrm{F}$. $\left(595^{\circ} \mathrm{C}\right.$.), the results of which are given in Tables 4, 5, and 6 . The most significant features developed may be summarized as follows:

1. The load which results in "no flow" in the second period, and, hence, permits infinite life at $1,100^{\circ} \mathrm{F}$. $\left(595^{\circ}\right.$ C.) approximates the proportional limit of the ordinary tension test at the same temperature.

2. At room temperatures the steel has the strongest tendency to strain harden, so that the load giving "no flow" in the second period is well above the proportional limit and even somewhat higher than the yield point of the tension test.

TABLE 4.-Results of flow tests of 0.24 per cent $C$ steel at room temperature

\begin{tabular}{|c|c|c|c|c|c|c|c|}
\hline Specimen number & $\begin{array}{c}\text { Test } \\
\text { unit } \\
\text { number }\end{array}$ & $\begin{array}{c}\text { A pplied } \\
\text { load } \\
\text { lbs./in. }{ }^{2} \\
\text { on original } \\
\text { area }\end{array}$ & \begin{tabular}{|} 
Elongation \\
at fallure, \\
per cent \\
in 2 inches
\end{tabular} & $\begin{array}{l}\text { Final re- } \\
\text { duction } \\
\text { of area }\end{array}$ & $\begin{array}{c}\text { "Initial } \\
\text { flow" inch } \\
\text { per inch }\end{array}$ & $\begin{array}{l}\text { Average } \\
\text { flow rate } \\
\text { in second } \\
\text { stage, inch } \\
\text { per inch } \\
\text { per hour }\end{array}$ & Lifo \\
\hline $\begin{array}{l}\text { F67 } \\
\text { F51 } \\
\text { F69 } \\
\text { F7053 } \\
\text { F55 } \\
\text { F63 } \\
\text { F64 } \\
\text { F54 } \\
\text { F75 } \\
\text { F767 }\end{array}$ & $\begin{array}{l}4 B \\
2 B \\
2 A \\
3 A \\
3 B \\
2 A \\
2 B \\
2 B \\
4 A \\
2 A \\
2 B \\
4 B \\
4 B \\
4 B\end{array}$ & $\begin{array}{l}24,500 \\
30,000 \\
40,000 \\
43,000 \\
48,500 \\
50,200 \\
52,000 \\
53,400 \\
53,700 \\
53,900 \\
54,000 \\
54,000 \\
\mathbf{5 4}, 000 \\
\mathbf{5 4}, 000\end{array}$ & 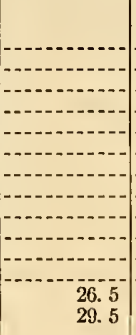 & $\begin{array}{r}\text { Per cent } \\
\end{array}$ & $\begin{array}{l}0.0030 \\
.0073 \\
.0065 \\
.0330 \\
.115 \\
.103 \\
.140 \\
.170 \\
.190 \\
.114 \\
(9) \\
(9) \\
(9) \\
(9)\end{array}$ & \begin{tabular}{l}
0 \\
0 \\
0 \\
0 \\
0 \\
0 \\
0 \\
0 \\
0 \\
0 \\
0 \\
-0 \\
\hdashline \\
\hdashline
\end{tabular} & $\begin{array}{l}\text { Hours } \\
(1) \\
(2) \\
(2) \\
(3) \\
(3) \\
(1) \\
(5) \\
(6) \\
(7) \\
(8) \\
(10) \\
(10) \\
0.20 \\
.07\end{array}$ \\
\hline \multicolumn{4}{|c|}{$\begin{array}{l}1 \text { Stopped at } 7 \text { hours. } \\
2 \text { Unbroken at } 117 \text { hours. } \\
\text { a Unbroken at } 787 \text { hours. } \\
\text { } 4 \text { Unbroken at } 190 \text { hours. } \\
\text { s Unbroken at } 187 \text { hours. }\end{array}$} & \multicolumn{3}{|c|}{$\begin{array}{l}\text { Unbroken at } 961 \text { hours. } \\
7 \text { Unbroken at } 72 \text { hours. } \\
8 \text { Unbroken at } 937 \text { hours. } \\
\text { Continuous. } \\
10 \text { Approximately, } 0,2 \text { hours }\end{array}$} & \\
\hline
\end{tabular}


TABLE 5.--Results of flow tests on 0.24 per cent $\mathrm{C}$ steel at $1,100^{\circ} \mathrm{F} .\left(595^{\circ} \mathrm{C.}\right)$

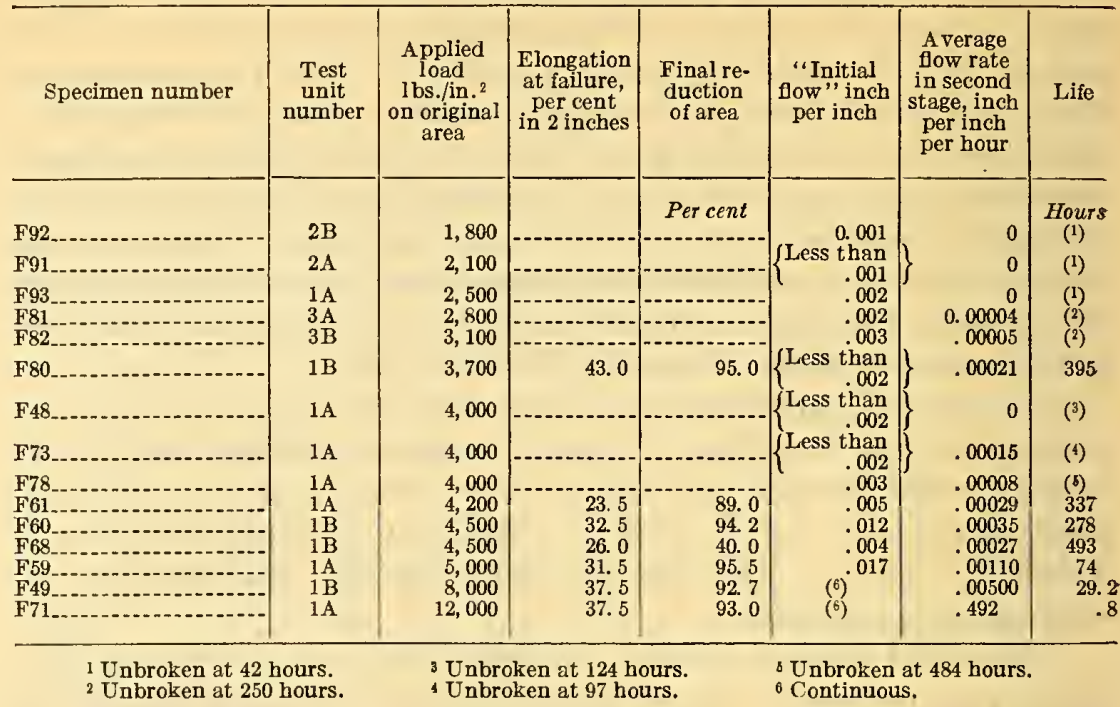

$\mathrm{T}_{\mathrm{ABLE}}$ 6.-Results of short-time tension tests of 0.24 per cent $C$ steel at various temperatures

TESTS BY THE AUTHORS

\begin{tabular}{|c|c|c|c|c|c|c|c|c|}
\hline \multirow{2}{*}{ Temperature of test } & \multicolumn{2}{|c|}{$\begin{array}{l}\text { Size of specimen } \\
\text { used }\end{array}$} & $\begin{array}{l}\text { Propor- } \\
\text { tional } \\
\text { limit }\end{array}$ & $\begin{array}{l}\text { Yield } \\
\text { point I }\end{array}$ & $\begin{array}{c}\text { Tensile } \\
\text { strength }\end{array}$ & $\begin{array}{l}\text { Breaking } \\
\text { strength }^{2}\end{array}$ & \multirow{3}{*}{$\begin{array}{c}\text { Elon- } \\
\text { gation in } \\
2 \text { inches } \\
\\
\text { Per cent } \\
30.0\end{array}$} & \multirow{3}{*}{$\begin{array}{c}\begin{array}{c}\text { Reduc- } \\
\text { tion of } \\
\text { area }\end{array} \\
\text { Per cent } \\
\quad 59.2\end{array}$} \\
\hline & Diameter & Length & \multicolumn{4}{|c|}{1,000 pounds per square inch } & & \\
\hline $\begin{array}{l}{ }^{\circ} F \\
70\end{array}{ }^{\circ} C$ & $\begin{array}{l}\text { Inch } \\
0.250 \\
\end{array}$ & $\begin{array}{r}\text { Inches } \\
2 \\
\end{array}$ & 20.0 & 33.0 & 66.7 & 130.0 & & \\
\hline $\begin{array}{ll}560 & (295) \\
560 & (295) \\
560 & (295) \\
560 & (295)\end{array}$ & $\begin{array}{l}.505 \\
.507 \\
.250 \\
.250 \\
\end{array}$ & $\begin{array}{l}2 \\
2 \\
2 \\
2 \\
\end{array}$ & $\begin{array}{r}17.5 \\
15.0 \\
15.5 \\
\end{array}$ & $\begin{array}{r}25.7 \\
26.7 \\
27.0 \\
-\end{array}$ & $\begin{array}{c}64.6 \\
-64.8 \\
77.4\end{array}$ & 116.2 & $\begin{array}{l}19.0 \\
21.5 \\
-\end{array}$ & $\begin{array}{r}50.0 \\
53.0 \\
- \\
-. .-\end{array}$ \\
\hline Average.- & -- & - & 16.0 & 26.5 & 68.9 & 116.2 & 20.2 & 51.5 \\
\hline $\begin{array}{ll}830 & (445) \\
830 & (445) \\
830 & (445)\end{array}$ & $\begin{array}{l}.505 \\
.502 \\
.250\end{array}$ & $\begin{array}{l}2 \\
2 \\
2\end{array}$ & $\begin{array}{r}10.8 \\
12.5 \\
-1 .-\end{array}$ & $\begin{array}{l}22.7 \\
22.0 \\
24.6\end{array}$ & $\begin{array}{r}47.0 \\
46.5 \\
-\end{array}$ & $\begin{array}{l}91.8 \\
84.8 \\
-1 .--\end{array}$ & $\begin{array}{l}34.0 \\
35.0 \\
-\end{array}$ & $\begin{array}{r}75.5 \\
76.0 \\
-\end{array}$ \\
\hline Average. & 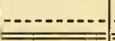 & -- & 11.6 & 23.1 & 46.8 & 88.3 & 34.5 & 75.8 \\
\hline $\begin{array}{ll}1,100 & (595) \\
1,100 & (595) \\
1,100 & (595) \\
1,100 & (595) \\
1,100 & (595)\end{array}$ & $\begin{array}{l}.505 \\
.505 \\
.505 \\
.505 \\
.505 \\
\end{array}$ & $\begin{array}{l}2 \\
2 \\
2 \\
2 \\
2 \\
\end{array}$ & $\begin{array}{l}3.0 \\
2.8 \\
3.0 \\
2.6 \\
\end{array}$ & $\begin{array}{r}11.7 \\
12.2 \\
15.3 \\
11.1\end{array}$ & $\begin{array}{l}22.5 \\
21.6 \\
26.8 \\
26.0 \\
23.5\end{array}$ & $\begin{array}{l}41.6 \\
45.9 \\
54.0 \\
60.8 \\
41.7 \\
\end{array}$ & $\begin{array}{l}42.0 \\
43.0 \\
39.0 \\
41.5 \\
40.5\end{array}$ & $\begin{array}{l}90.4 \\
91.4 \\
88.2 \\
90.0 \\
90.4 \\
\end{array}$ \\
\hline . Average.. & & & 2. 8 & 12.6 & 24.1 & 48.8 & 41.2 & 90.1 \\
\hline
\end{tabular}

TESTS AT THE WESTINGHOUSE ELECTRIC \& MFG. CO.

\begin{tabular}{|c|c|c|c|c|c|c|c|c|}
\hline $\begin{array}{l}81 \quad(27) \\
560 \quad(293) \\
830 \quad(445) \\
830 \quad(445) \\
1,100 \quad(595)\end{array}$ & $\begin{array}{l}0.505 \\
.505 \\
.505 \\
.505 \\
.505\end{array}$ & $\begin{array}{l}3 \\
3 \\
3 \\
3 \\
3\end{array}$ & $\begin{array}{r}\text { 17. } 5 \\
\text { 12. } 0 \\
9.0 \\
9.0 \\
3.0\end{array}$ & $\begin{array}{l}28.0 \\
25.5 \\
22.9 \\
23.3 \\
12.5\end{array}$ & $\begin{array}{l}60.0 \\
65.6 \\
45.2 \\
45.6 \\
23.3\end{array}$ & 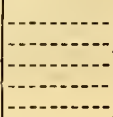 & $\begin{array}{l}41.0 \\
30.4 \\
45.2 \\
45.2 \\
55.0\end{array}$ & $\begin{array}{l}63.0 \\
53.0 \\
77.7 \\
77.7 \\
90.2\end{array}$ \\
\hline
\end{tabular}

1 Yield points taken as the load giving 0.2 per cent deformation.

2 This refers to the load at the moment of fracture; it is obtained by dividing the load in pounds by the reduced area of the fractured section.

${ }_{3}$ These tests were made by P. G. McVetty. See footnote 7 of the text, p. 637. 
It is evident from these results and those previously discussed that one of the principal effects of increase above atmospheric temperatures is to reduce the strain-hardening ability of the steel, and, as shown in Figure 11, the load-carrying capacity, from the standpoint of infinite life alone, drops rapidly from values well above the yield point at room temperature until it approximates the proportional limit of the short-time tensile test at about $750^{\circ} \mathrm{F} .\left(400^{\circ} \mathrm{C}\right.$.). It continues to approximate the proportional limit values as the temperature is raised up to $1,100^{\circ} \mathrm{F}$. $\left(595^{\circ} \mathrm{C}\right.$.).

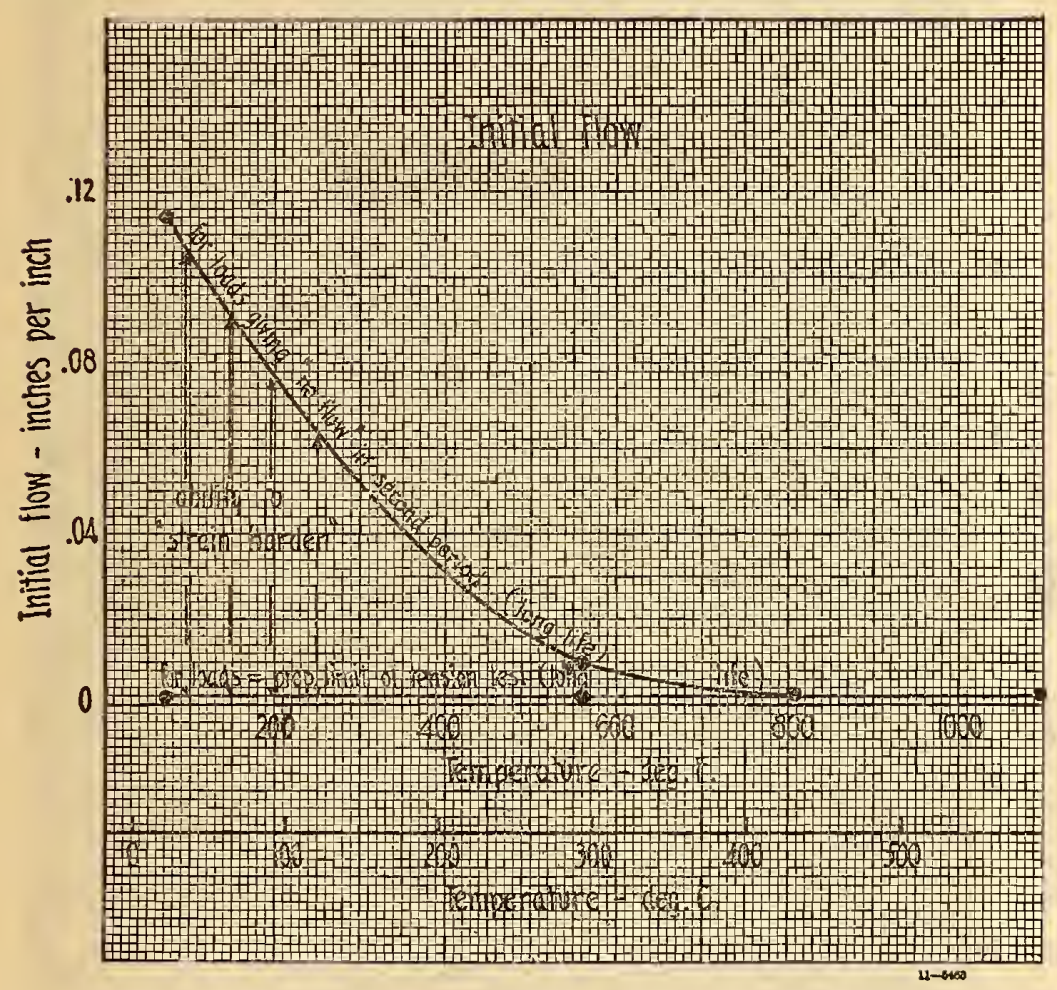

Fig. 10.-Initial flow in 0.24 per cent $C$ steel at various temperatures for loads approximating the proportional limit of short-time tension tests and loads giving "no flow" in the second period of long-time tests

Thus, it appears that the customary proportional limit determination is a suitable criterion of long life at the highest temperatures (between, say, 700 and $1,100^{\circ} \mathrm{F}$. (370 and $595^{\circ} \mathrm{C}$.)), but may be too conservative at lower temperatures. However, this is not generally true, for under ordinary conditions two requirements must be fulfilled insofar as the mechanical properties are concerned. These have already been referred to and are (1) that the metal must have a suitable life and (2) during such life it must not deform appreciably. It is, of course, true that in some cases appreciable deformation can be allowed, but as a general rule the second requirement of low deformation must be met. 
While at room temperature and $560^{\circ} \mathrm{F}$. $\left(295^{\circ}\right.$ C.) loads greatly in excess of the proportional limit may be applied and very long life obtained due to the marked ability of the steel to strain-harden, such self-hardening takes place only after a considerable initial flow,

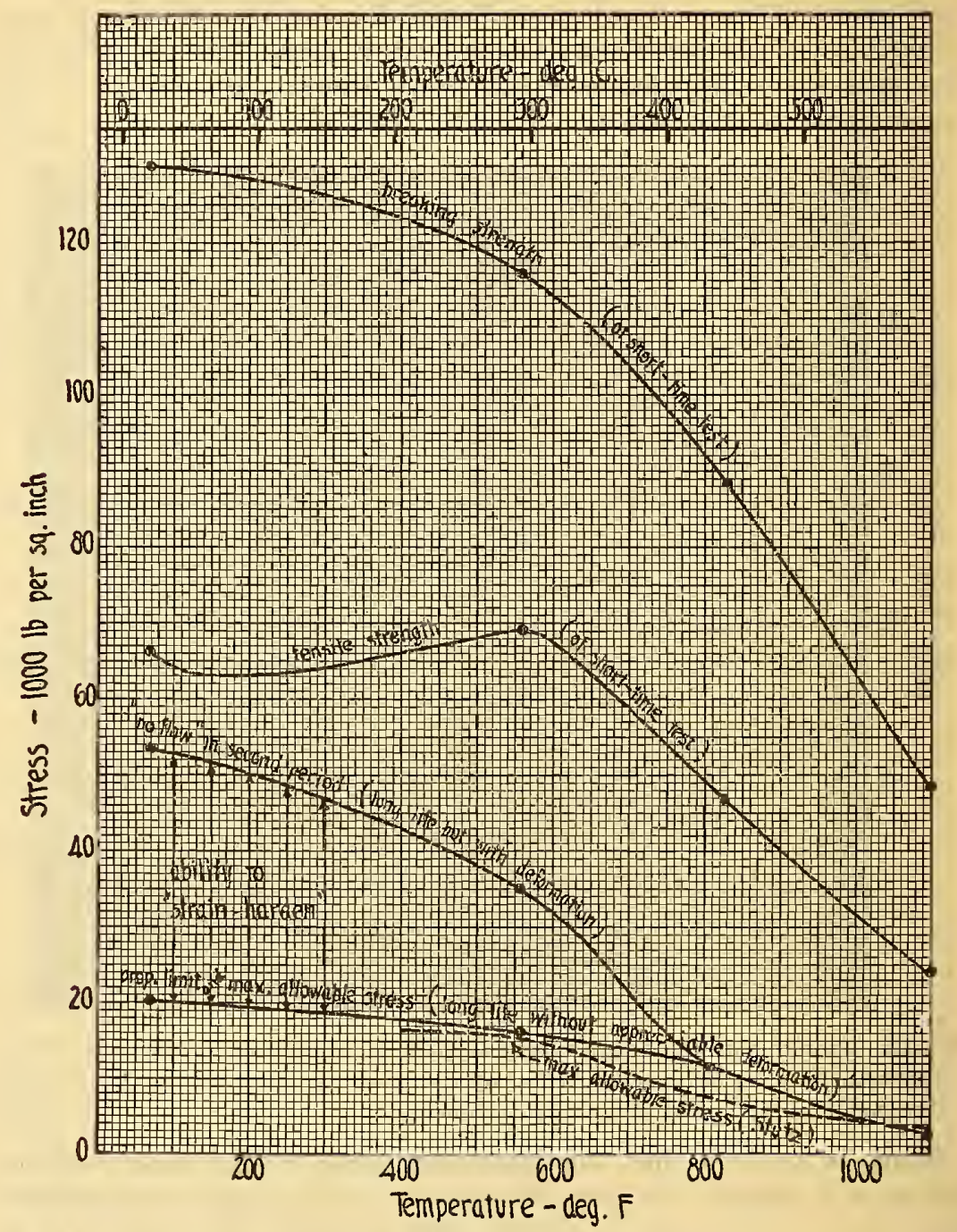

FIG. 11.-Comparison of results obtained with 0.24 per cent $C$ steel in long-time and the customary short-time tension tests at various temperatures

which in most cases of practical service would be highly objectionable. At the highest temperatures the maximum allowable stress was limited by the flow rate in the second stage, but at the lower temperatures it is primarily a function of the initial flow or how much deformation can be absorbed. 



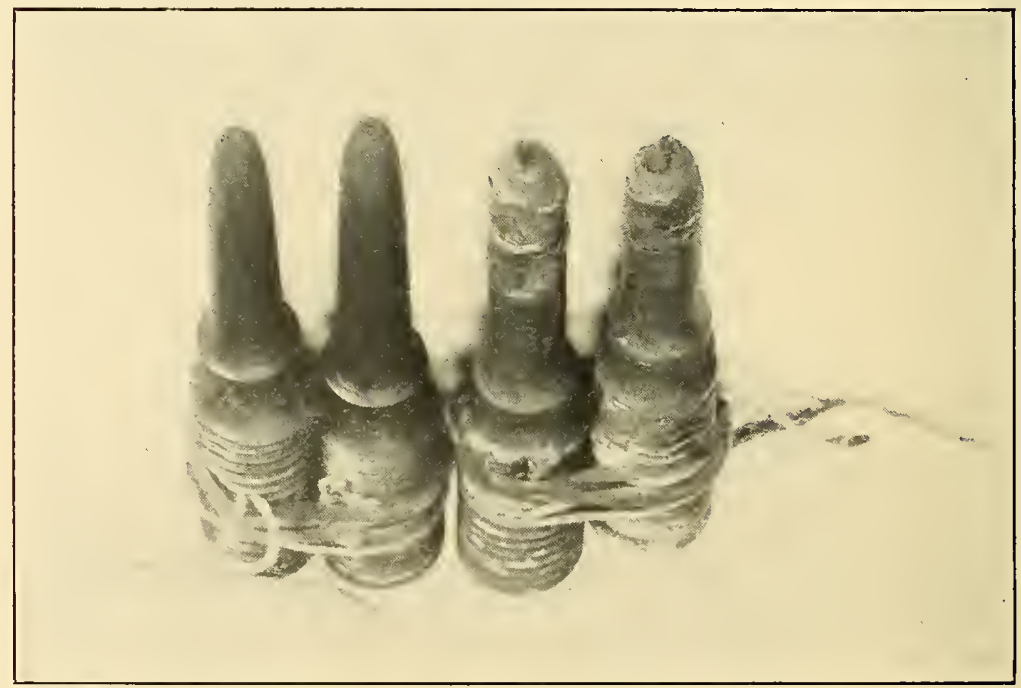

FIG. 12.-Oxidation of 0.24 per cent $C$ steel stressed for various times at $1,100^{\circ} \mathrm{F} .\left(595^{\circ} \mathrm{C}.\right)$

Note the difference in degree of oxidation between the specimen heated for 490 hours and that for 6 hours. 
In view of this change in the controlling factor with temperature, it will be of value to compare the initial flow for loads giving "zero flow rate" in the second period with the initial flow resulting from loads equal to the respective proportional limits of the short-time tension test. These data have been incorporated in Figure 10 and show quite clearly that where both long life and freedom from appreciable deformation are required the limiting loads approximate the proportional limit at the respective temperatures. In case appreciable deformation can be absorbed at temperatures up to about $400^{\circ}$ F. $\left(205^{\circ}\right.$ C.) somewhat higher loads can be applied. The distance between the upper and lower curves in Figure 10 gives at any temperature a relative measure of the strain-hardening ability of the steel and shows that this disappears in the neighborhood of $750^{\circ}$ F. $\left(400^{\circ}\right.$ C. $)$.

While, as previously stated, only the mechanical properties are to be considered in this report, it is necessary to refer briefly to the chemical stability of low-carbon steel. At temperatures above about $900^{\circ} \mathrm{F}$. $\left(480^{\circ} \mathrm{C}\right.$.) there was a strong tendency toward progressively increasing oxidation when heated in air under the existing experimental conditions. This is illustrated in Figure 12, in which is given a comparison of two specimens held, respectively, about 6 and 490 hours under load at $1,100^{\circ} \mathrm{F}$. $\left(595^{\circ} \mathrm{C}\right.$.). In the latter case the oxidation reduced somewhat the effective cross sectional area and so gave a progressively increasing stress concentration which increased the rate of flow in the second stage and shortened the life of the steel. Variable oxidation quite probably accounts for the lack of concordance in the rate of flow observed in some of the duplicate tests made at $1,100^{\circ} \mathrm{F}$. $\left(595^{\circ} \mathrm{C}\right.$.) (Table 5). Temperatures above about $900^{\circ} \mathrm{F}$. $\left(480^{\circ}\right.$ C.) form a sensitive range for the steel under the conditions of test and with appreciable or variable oxidation variations are to be expected in the manner of flow and the relations between the long-time and short-time tests.

\section{GENERAL DISCUSSION}

The described tests have given numerical values for the load-carrying ability of a low-carbon steel at different temperatures, and it will be of interest to compare them with data obtained by other investigators on similar material.

In Figure 13 is given a "strength-temperature" curve successfully used by C. C. Stutz ${ }^{5}$ in calculating the maximum allowable stresses for "medium hard" and "mild" carbon steels subjected to service at temperatures up to 1,000 to $1,600^{\circ} \mathrm{F}$. $\left(540\right.$ to $870^{\circ} \mathrm{C}$.). The changes in "strength" with temperature are given in terms of the value at

5 This information was obtained by one of the authors as a member of the joint research committee of the A. S. T. M. and A. S. M. E. on "Tho effect of tomperature on the properties of motals." 
ordinary temperatures, and Stutz makes the following comments concerning the use of his chart:

When in 1906 I was confronted with designing problems requiring a knowledge of the behavior of ordinary steels at high temperatures, I found that very little information was available. I managed, however, to gather data I embodied in the diagram submitted (fig. 13).

At that time I was designing machinery, part of which had to run continuously in a temperature of $1,000^{\circ} \mathrm{F}$. $\left(540^{\circ}\right.$ C. $)$. Some years later I worked out some designs where certain parts ran constantly in the temperatures of $1,600^{\circ} \mathrm{F}$. $\left(870^{\circ} \mathrm{C}\right.$.). In both these and other instances I made use of the diagram submitted with very satisfactory results as far as operating was concerned.

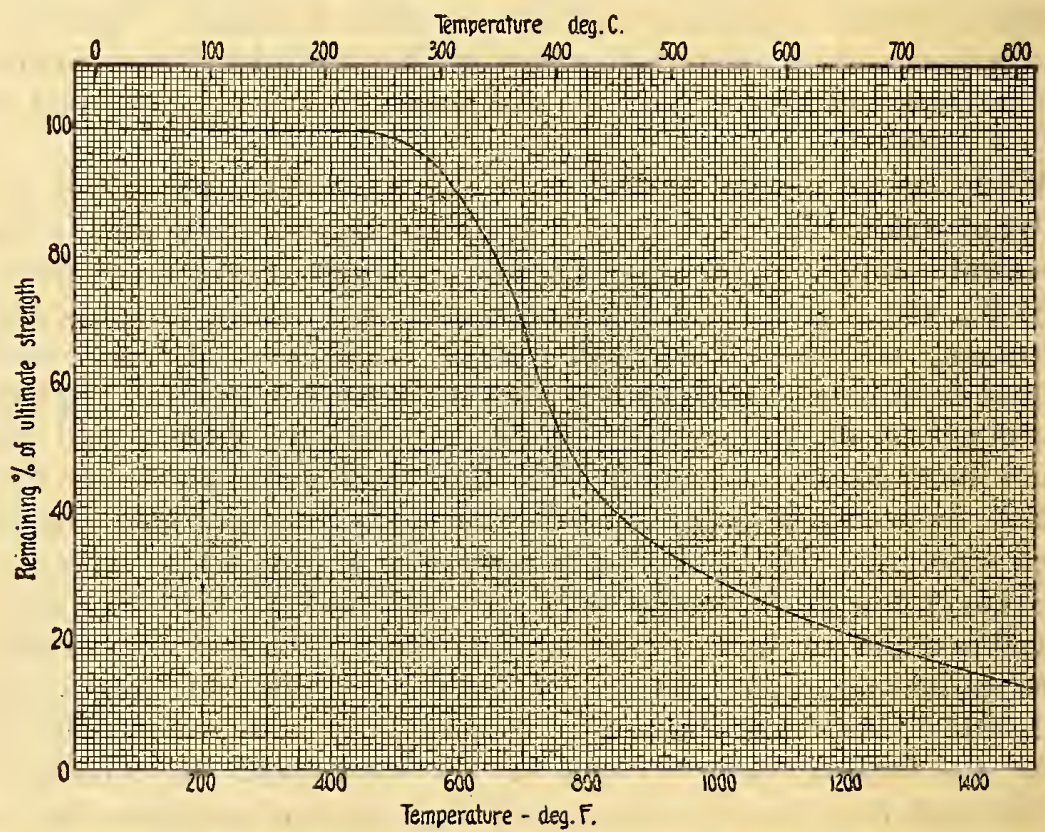

FIG. 13.- "Strength-temperature" relations for carbon steels successfully used by Stutz in computing maximum allowable stresses for commercial service

While I fully realize that the information contained on the chart submitted is only approximate and will probably be greatly modified by recent and more careful determinations, yet, having found it very satisfactory and evidently on the safe side, I feel that it is valuable as an approximation.

Up to $400^{\circ} \mathrm{F}$. $\left(205^{\circ} \mathrm{C}\right.$.) temperature was not considered. In the range 400 to $1,000^{\circ} \mathrm{F}$. (205 to $540^{\circ} \mathrm{C}$.) a factor of safety of 4 was taken based on the ultimate strength of the steel in order to obtain the allowable stress.

In the range of 1,000 to $1,600^{\circ} \mathrm{F}$. $\left(540\right.$ to $870^{\circ} \mathrm{C}$.) the factor of safety wa gradually increased from 4 to 6 .

In the range of 1,250 to $1,600^{\circ} \mathrm{F}$. (675 to $870^{\circ} \mathrm{C}$.) the added precaution was taken to avoid as much as possible horizontal members unless additional supports were provided to counteract deflection.

The above rules were used only with steels obtainable in the open market having an ultimate strength up to $80,000 \mathrm{lbs} . / \mathrm{in} .^{2}$ 
The safe working stresses derived from Stutz's chart have been incorporated in Figure 11 for comparison with the authors' tests, and a surprisingly close agreement is observed. Stutz's values are somewhat lower than the authors,' except at the highest temperature, but, as stated above, they are considered to be on the safe side. That the proportional limits of the short-time test so closely check maximum allowable stress values which have been successfully used in service under a variety of conditions gives strong support to the conclusions drawn and materially increases the usefulness of the data which have been obtained.

Insofar as the described experiments are concerned, confirmation is given to the opinion expressed by Brearley ${ }^{6}$ that carefully determined stress-strain relations give adequate information for computing allowable service stresses. However, additional work is required before the same relations can be considered to apply generally to ferrous products. They probably do in carbon and the customary structural alloy steels, but should be confirmed in tests of high-alloy content austenitic steels or some other metals differing widely in composition from the steel used in this investigation.

Probably a word of caution at this point will not be out of place. The numerical values for allowable stress which were derived from experiments on a single lot of 0.25 per cent $\mathrm{C}$ steel must not be considered to apply generally to this type, as it is well known that different heats will show variations in mechanical properties even though the proportions of carbon, manganese, etc., are identical. Probably 80 per cent of the derived values will safely take care of variations between different heats.

Likewise, it is not to be expected that proportional limits in shorttime tests will so closely approximate the load-carrying ability shown by flow tests unless they are determined by methods similar to those used by the authors. To gain some idea of how closely determinations in different laboratories may be expected to check the authors' long and short time tests, arrangements were made with The Westinghouse Electric \& Manufacturing Co. ${ }^{7}$ for comparison tests on the particular heat of steel used. The results are included in Table 6 and typical stress-strain diagrams, from which the proportional limits were determined in both sets of tensile tests, are reproduced in Figure 14.

Some differences in values would be expected, as commercial hotrolled low-carbon steel plates are not entirely homogeneous either chemically or physically; likewise there are variations in test methods, including rates of stress application, time of heating before the tests

- See footnote 1, p. 620 .

7 The authors are indcbted to T. D. Lynch, manager, matcrial and process ongincering dopartment, for arranging for theso tests and to P. G. McVotty for carrying out tho work with tho accurato oquipment described by Wilhelm in the Proceedings, A. S. T. M. 24, pt. 2, p. 142; 1924. 
are made, etc. Under such conditions exceedingly good agreement is shown, for the results obtained in the two different laboratories

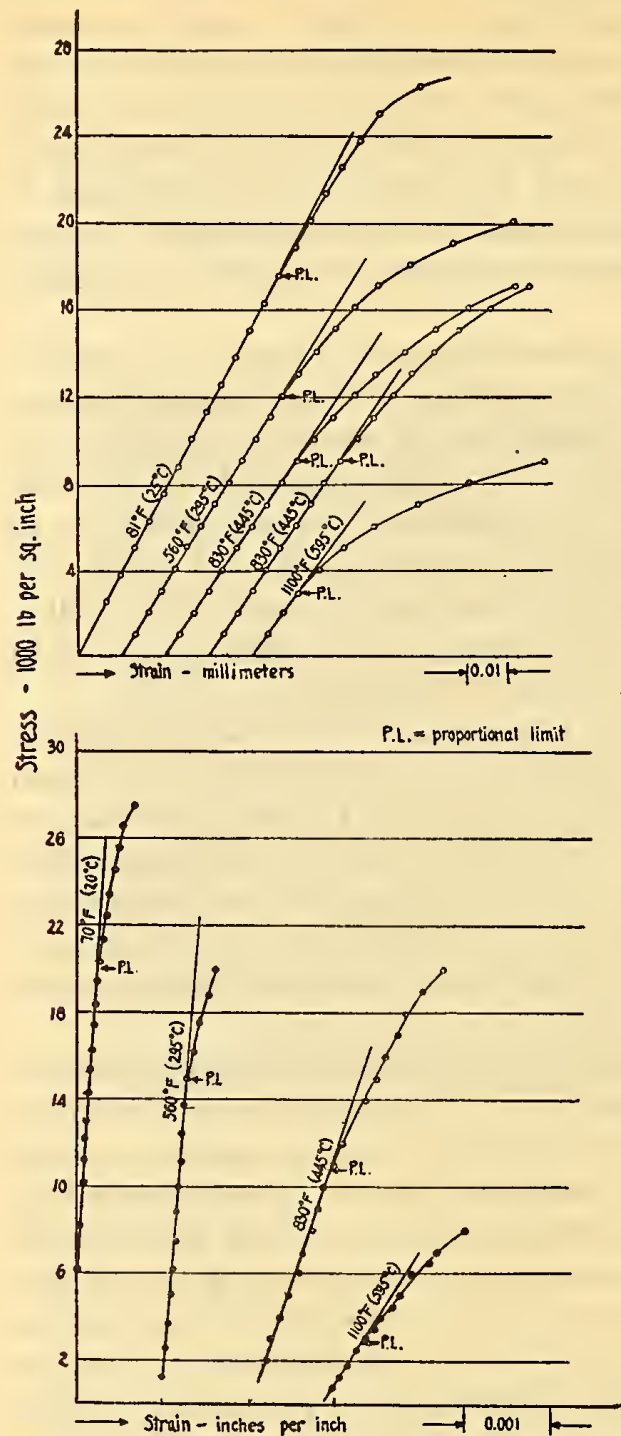

F'IG. 14.-Comparison of stress-strain diagrams and proportional limits at various temperatures as determined by the authors and $\mathrm{McV}$ etty

The upper curves were obtained at the Westinghouse Electric and Manufacturing Co. by P. G. McVetty (see footnote 7 of the text, p. 637); the lower curves have been selected from determinations by the authors. check in general as closely as duplicate determinations made in the one laboratory. Especially is this true of the elastic properties, including proportional limits, and leaves no doubt regarding the practical value of the described relations between the short-time tests and the flow of this steel under sustained loads at corresponding temperatures.

With the accurate extensometer used by McVetty, by which it is possible to detect smaller deviations from the proportionality between stress and strain than with the authors' equipment, somewhat lower proportional limits would be expected especially in those cases in which the departure from the straight line relationship takes place gradually. These conditions exist at ordinary temperatures and $560^{\circ} \mathrm{F}$. $\left(295^{\circ} \mathrm{C}\right.$.), as shown in Figure 14 and Table 6, and as a result the proportional limits obtained by McVetty are a few thousand pounds lower than the values reported by the authors. With rise in temperature the stress-strain curves tend to "break" more sharply and even closer agreement is observed in the results obtained in the two laboratories.

It is of special interest that the largest of these small variations were found at the lowest temperatures where the steel has maximum 
strain hardening ability and the proportional limits are well below the loads permitting infinite life; closest agreement was obtained at $1,100^{\circ} \mathrm{F}$. $\left(595^{\circ} \mathrm{C}\right.$.) where the proportional limit approximates the maximum load permitting very long life.

These comparisons indicate (1) that carefully determined stressstrain relations give a satisf actory criterion of the load carrying ability of low-carbon steel and (2) that it is possible to duplicate results in different laboratories with a degree of accuracy quite satisfactory for practical purposes.

In view of the results obtained, it is probable that much of the dissatisfaction with short-time tests, recently emphasized, is due to improper application and not alone to the character of published data. Even after an elaborate series of long-time tests have developed so-called safe working loads for various metals, difficulties will be encountered in service when no allowance is made for the auxiliary stresses so readily introduced by differential expansions and contractions or in other ways. Localized heating and likewise constitutional or chemical instability for given types of service may each hasten failure. No set of design loads, no matter how carefully worked out, will be satisfactory for all types of service unless they are based on far too liberal factors of safety for current engineering practice. In each case the operating conditions must be known in detail and available data applied with care and a knowledge of other fundamental characteristics of the materials. Without doubt, what is now most needed in this field is a correlation between tests made in different laboratories and the behavior of metals in various types of practical service.

\section{CONCLUSIONS}

The principal conclusions to be drawn may be summarized as follows:

1. The total flow producing fracture when low-carbon steel is subjected to a fixed total load in tension at approximately constant temperature takes place in three distinct steps, the importance of which vary with the applied load and temperature.

2. These three stages of flow are (1) an initial flow; (2) a secondary flow at fairly constant rate, which is also considerably less than the rate during the first and third periods; and (3) a final rapid flow just before fracture.

3. As the constant applied load is increased, the initial flow and the rate of flow in the second period increase and the life of the steel decreases. The final rapid flow begins when the reduction in cross section accompanying appreciable elongation has raised the unit stress to a definite load at each temperature. 
4. The relation between decrease in applied load and increase in life is approximately hyperbolic.

5. At atmospheric temperatures there is a small difference in the loads permitting very long life and those producing fracture in a few moments. As the temperature is raised the increase in life with decrease in applied load becomes more gradual. An important effect of temperature increase is to reduce the strain-hardening ability of the steel. This is a maximum at ordinary temperatures and decreases until it becomes zero in the neighborhood of 750 to $800^{\circ} \mathrm{F}$. (400 to $425^{\circ} \mathrm{C}$.). As a result the principal factor governing the maximum allowable stress varies with temperature and the type of service. When both long life and freedom from appreciable deformation are required, the maximum allowable load closely approximates the proportional limit of the authors' short-time tests and similar tests at corresponding temperatures carried out independently at another laboratory. These proportional limits were found to closely approximate the maximum allowable stress values successfully used by an engineer for the design of commercial equipment operating at high temperatures. In the range 70 to about $600^{\circ} \mathrm{F}$. (20 to $315^{\circ}$ C.) higher working stresses can be used if appreciable deformation can be taken care of and long life is the primary requirement.

Acknowledgment is made to H. C. Cross, laboratory aid, and P. F. Brandt, laboratory assistant, for carrying out most of the tests at room temperatures and $1,100^{\circ} \mathrm{F}$. $\left(595^{\circ} \mathrm{C}\right.$.).

Washington, June 3, 1925. 